\title{
Transforming a Sequence of Microbiology Courses Using Student Profile Data
}

\author{
ROSA J. BUXEDA ${ }^{1 *}$ AND DEBORAH A. MOORE ${ }^{2}$ \\ Department of Biology ${ }^{1}$ and Department of Mathematics, ${ }^{2}$ University of Puerto Rico at Mayagüez, Mayagüez, \\ Puerto Rico 00681-9012
}

A study was performed in the General Microbiology and Industrial Microbiology courses to increase research awareness at an early stage of the educational process and to establish collaboration between students in an Industrial Microbiology program and industry. In both courses, the professor helped students determine their learning styles and then used these data to design activities in order to accomplish the above objectives. In both the treatment and the control sections, students learned about strategies to optimize learning based on their learning styles. A cooperative learning format was introduced to promote active learning and team-building skills. The diverse learning styles data profile was used by students during cooperative learning activities for effective team integration. In the General Microbiology course, a mentor-mentee structure was introduced to expose students to research in microbiology by visiting research facilities on campus. This structure was an addition to the regular curriculum, which meets American Society for Microbiology curriculum recommendations. The results suggest an increase in interest in research by students. In the Industrial Microbiology course, a strategy was introduced to establish collaboration with industry in which students visit the workplace and identify microbial processes, microbiologist roles, and skills needed by microbiologists. Evaluation of these topics using pre- and posttest data indicates a significant increase in acquired knowledge relevant to daily workplace environments with the reformed course. In both courses, students gain information early in their academic experience to help them consider participation in research experiences while providing them with real-world experience toward the end of their academic careers, when they see the need for it.

Decades of experimental psychology have indicated that in order to promote learning we need to develop approaches that emphasize applications and interpersonal collaborations. Documentation of the social nature of learning is long standing. It can be traced to theories of social interdependence as well as to cognitive development and behavioral learning $(6,14,15,17)$. Learning requires reflection and occurs best in a cultural context that provides both enjoyable interaction and substantial personal support (9). For example, both student-student and student-faculty interactions have a great impact on educational outcomes (4).

Cooperative learning has been examined in precollege and college studies as a teaching strategy to promote active learning in a group environment. This strategy has been referred to as the most researched of all instructional methods $(12,18)$. Although it initially influenced more elementary and secondary activities, there is a definite growing interest in cooperative learning in higher education (19).

In 1995, Barr and Tagg (5) proposed a transformation of the higher education process, a shift in the educational paradigm. In this proposal, faculty become designers of learning environments rather than just lecturers. The new learning environments are cooperative, learner centered, and learner controlled. It has been reported that "too many graduates go out into the workforce ill-prepared to solve problems in a cooperative way, lacking the skills and motivation to continue learning" (1).

*Corresponding author. Mailing address: University of Puerto Rico at Mayagüez, P.O. Box 9012, Mayagüez, PR 00681-9012. Phone: (787) 832-4040 ext. 2174. Fax: (787) 831-5249. E-mail: r_buxeda@rumac.upr.clu.edu.
In the last decade, the microbiology field has experienced a transformation in the education process. The American Society for Microbiology (ASM) took the lead in microbiology education through the establishment of its annual Undergraduate Education Conferences in 1994. Some major outcomes of the conferences have been the development of recommendations for an undergraduate microbiology curriculum as well as the compilation of cooperative learning activities. These recommendations included cognitive processes as well as communication and interpersonal skills $(2,8)$.

At the University of Puerto Rico at Mayagüez (UPRM), an industrial microbiology curriculum to support a four-year B.S. degree was established in response to local industry needs. The General Microbiology/Industrial Microbiology course sequence is taken usually by students in this curriculum in preparation for the field. Local industry is composed largely of pharmaceutical companies. Puerto Rico's population is slightly under four million, but the island is home to 5 local, 47 U.S., and 9 foreign pharmaceutical companies.

Some common goals of the UPRM industrial microbiology curriculum are to give the students a general education, to provide the students with a more specific education in microbiology, to teach them to be lifelong learners, and to prepare them for the modern workforce. In a report of industrial needs in Puerto Rico (3), some of the most important skills for incoming employees were teamwork and interpersonal skills. In the area of general knowledge, the report also included knowledge of local and federal regulatory agencies as being very important. This article describes an action research project that redesigned the Industrial Microbiology course and its prerequisite, the General Microbiology 
course, to increase student exposure to research in microbiology and to increase student awareness of industrial roles of microbiologists, thus providing students a vision of research and a better preparation for the workforce.

\section{STUDY IN GENERAL MICROBIOLOGY}

The goals of the study were to determine and, if needed, increase meaningful student exposure to microbiology research. More specifically, the study attempted to provide students with active, meaningful learning by presenting the information within a framework that prepared them for lifetime learning. To accomplish this goal, one objective was to determine the degree of student awareness of research in the field and to link course theory to research in an active environment. Another objective was to improve students' metacognitive and group interaction skills by teaching the process of learning and by explaining the different variety of learning styles.

To identify student prior knowledge of microbiology research, a short questionnaire was administered to three sections of General Microbiology on the first day of class. The results of the questionnaire indicated that students' knowledge of ongoing research in microbiology was poor and that few had ever visited a microbiology research laboratory. It also identified that their interest in having research experiences was poor.

On the basis of the results of the questionnaire, the professor decided to conduct an experiment with three of her sections. One section was randomly assigned as the control group, and the other two were assigned as the treatment group. There was no difference between the treatment given in the two sections referred to collectively as the treatment group. The content covered in both the treatment and the control groups was the same and conforms to ASM recommendations; however, the control group was exposed only to a lecture format, while the treatment group was engaged in cooperative learning activities (7). All sections used similar evaluation instruments, instructor-created examinations.

Students in both the control and the treatment groups were asked to identify their learning styles by using a questionnaire on learning styles developed by Soloman and Felder (refer to end note). Students cited their preference on a scale for each dichotomous learning style dimension as being low, moderate, or high. As shown in Table 1, the Soloman and Felder model presents learning in terms of five dimensions: perception, input modality, organization, processing, and understanding $(10,11)$.

Both the treatment and the control groups preferred active, sensorial, visual, and sequential learning. The results for the control group were $70 \%$ active, $78 \%$ sensorial, $87 \%$ visual, and $83 \%$ sequential. The results for the treatment group were $58 \%$ active, $75 \%$ sensorial, $89 \%$ visual, and $62 \%$ sequential. Note that the instrument did not measure the organization dimension to determine the preference for inductive versus deductive learning. The professor asked students in the control group to use this information to develop strat- egies to help themselves in the class.

Formal cooperative learning was used in General Microbiology. Small groups of four to six students worked together for the entire semester to achieve a shared learning goal. The professor explained the methodology of cooperative learning, outlining its most important features: positive interdependence, individual accountability, and interpersonal relationships. Students determined their individual learning style profiles and used them to design the team profile. The learning style information was used for all individual learners to optimize their learning strategies and to become aware of their group's diversity. This awareness was used to complement skills and optimize the group's performance. For example, students mentioned that knowing that some group members were verbal and others were visual helped them understand how to divide the tasks of who should write the report and who should work on its diagrams. A global student indicated that he finally realized why it was difficult for him to work in groups before, since most members want to go step-by-step while he needed to know the overall process. His group decided to dedicate a section of each group session to looking at the big picture to help accommodate his learning style. The professor decided to include this emphasis on teamwork and cooperative learning in the treatment not only because of the solid research in favor of coopera-

TABLE 1. Learning style dimensions: the extremes of the different learning styles offered by Soloman and Felder

\begin{tabular}{|c|c|}
\hline $\begin{array}{c}\text { LEARNING } \\
\text { STYLE }\end{array}$ & DESCRIPTION \\
\hline Perception & $\begin{array}{l}\text { Intuitive vs. sensorial } \\
\text { Some students learn using their } \\
\text { intuition to search for meaning; } \\
\text { others use their senses to focus } \\
\text { on what is happening. }\end{array}$ \\
\hline Input modality & $\begin{array}{l}\text { Verbal vs. visual } \\
\text { Some students learn by listening } \\
\text { or writing; others prefer to see } \\
\text { pictures and diagrams. }\end{array}$ \\
\hline Organization & $\begin{array}{l}\text { Deductive vs. inductive } \\
\text { Some students organize } \\
\text { information by beginning with } \\
\text { rules and then deducing facts; } \\
\text { others learn inductively by } \\
\text { organizing information to find } \\
\text { patterns. }\end{array}$ \\
\hline Processing & $\begin{array}{l}\text { Reflective vs. active } \\
\text { Some students can learn } \\
\text { reflectively, thinking everything } \\
\text { through; others learn actively, } \\
\text { doing things and experimenting } \\
\text { to see what happens. }\end{array}$ \\
\hline Understanding & $\begin{array}{l}\text { Sequential vs. global } \\
\text { Some students understand } \\
\text { material when it is introduced } \\
\text { sequentially, step-by-step; others } \\
\text { need to see the overall picture. }\end{array}$ \\
\hline
\end{tabular}


tive learning $(4,13)$, but also because the learning style inventory for the class denoted a preference for active learning, and $85 \%$ of Puerto Rican industries report that the ability to work in groups is necessary for incoming employees (3).

The professor monitored team performance through monthly team presentations given as oral reports. Each group's presentation was made by a single member selected at random by the professor. This helped to develop individual accountability and positive interdependence within the groups. To ensure that each team was functioning as it should, individual team members completed a form evaluating themselves and their peers on the following criteria: appropriate use of time, participation in meetings, completion of assigned task, organization, and contribution of ideas, among others. This periodic team evaluation helped the group and the professor process how effectively the team members were working together.

Each group was assigned a mentor. The mentor was an upper-level undergraduate student who previously had passed the course with a grade B or better and who had research experience. The mentors met for $1.5 \mathrm{~h}$ each week with their groups. Students visited the following on-campus research laboratories: electron microscopy, food microbiology, microbial ecology, microbial physiology, molecular biology, mycology, and virology. The mentors also united the groups to give them orientation workshops on research opportunities for undergraduates. Attendance was taken at each meeting.

The mentor, with assistance from the professor, facilitated the group dynamic and the integration of the visits to the laboratories to correspond with course content. This process benefited the groups, but it also benefited the mentors, allowing them to have the opportunity to learn by teaching. In addition to the mentoring meetings, students in the treatment group were asked to interview a faculty member doing research in microbiology. They documented all their experiences in individual portfolios in which they

- reported on their learning profiles,

- reflected on their learning experience,

- evaluated their team skills and those of their

peers, and

- documented six activities, including a description of the research project.

\section{RESULTS IN GENERAL MICROBIOLOGY}

On the final day of class, a longer questionnaire was administered to both the control and the treatment groups to evaluate the course role in research awareness. Significant differences were found in favor of the treatment group in five of the seven common items on the questionnaire. These items showed an increase in interest and awareness of research, issues directly targeted in the treatment. They also showed improvement in issues indirectly addressed in the treatment, including opportunities to develop writing skills and to reflect on their learning process during the course. Two common comments from the treatment group were that the approach was a good experience which should also be used in other courses and that the course was a lot of work. Here are some sample comments (translated from Spanish) when students were asked about the course in an open-ended questionnaire item: I loved the experience; this should be done in other courses; keep doing this in the future, it helped me; I would love to visit the research labs in other areas; the course helped me to plan for my future; too much work; I loved the experience, but the portfolio preparation took a lot of my time.

Although one student mentioned the heavy workload of the portfolios, a few students specifically mentioned them as excellent tools for learning. Many made specific remarks about the visits to the laboratories. One student stated, "I had no idea of what was going on behind those [laboratory] doors."

An analysis of the data indicates two major findings. First, both the control and the treatment groups felt they had significantly improved their knowledge of ongoing microbiology research. However, interest in conducting research in the treatment group significantly increased, while interest in the control group slightly dropped. The other finding was that students in the control group had found out about the mentoring process used in the treatment and, despite the extra workload outside class, 63\% reported that they would have liked to participate in the mentoring experience. One specific comment addressed this well: "It is not the same to listen to a research project as it is to go and see the facilities." See Table 2 for more details.

Although attrition rates tend to be low in the General Microbiology course, the grade distributions differed slightly in the two sections in the experiment. Slightly more students successfully completed the course in the treatment group than in the control group. Also, significantly more students earned a grade of $\mathrm{A}$ in the treatment group. Refer to Table 3.

\section{STUDY IN INDUSTRIAL MICROBIOLOGY}

The same professor who conducted the experiment in the General Microbiology course was assigned to teach the only section of the Industrial Microbiology course during the spring semester. In order to prepare for this course, the professor collaborated with local industries to incorporate skills needed in the workplace (3). On the first day of class, information was gathered on the students enrolled in the course. The student profile indicated that only $3 \%$ of the student population had prior experience in industry and that $71 \%$ indicated no knowledge of the largest industry in Puerto Rico, pharmaceutics. The course was required for graduation for $69 \%$ of the students enrolled, with $70 \%$ of the entire population in their senior year and $17 \%$ in their junior year. In addition, few students were familiar with their possible role in industry or with the many other related items that affect industry workers. Using the Soloman and Felder test, the professor also found that $58 \%$ of the students preferred active over reflective learning, $77 \%$ preferred sensorial over intuitive learning, $87 \%$ preferred visual over verbal learning, and $65 \%$ preferred sequential over global learning.

The professor incorporated the student profile informa- 
tion to modify course content and activities to meet the students' needs. Students were divided in formal groups of five and given training in cooperative learning. They used this information to work better with their groups and to understand the diversity of the learning styles of their group's members.

Each team was assigned an industry. The group had to visit the industry and interview a microbiologist in that industry. Based on their visit and their interview, they had to identify the following:

- the roles of microbiologists in that industry,

- the microbial products of that industry,

- the microbial process associated with the industrial environmental process,

TABLE 2. Questionnaire results for General Microbiology ${ }^{a}$

\begin{tabular}{|c|c|c|}
\hline \multirow[t]{2}{*}{ Questionnaire item } & \multicolumn{2}{|c|}{ Avg response for group } \\
\hline & $\begin{array}{c}\text { Control } \\
\text { (1 section, } \\
24 \text { students) }\end{array}$ & $\begin{array}{l}\text { Treatment } \\
(2 \text { sections, } \\
53 \text { students }) \\
\end{array}$ \\
\hline $\begin{array}{l}\text { Knowledge of } \\
\text { ongoing research in } \\
\text { microbiology }\end{array}$ & $3.2(+1.0)$ & $3.3(+1.4)$ \\
\hline $\begin{array}{l}\text { Previous visits to } \\
\text { microbiology } \\
\text { research laboratories }\end{array}$ & $1.8(-0.2)$ & $3.4(+1.8)$ \\
\hline $\begin{array}{l}\text { Interest in conducting } \\
\text { research }\end{array}$ & $2.3(-0.2)$ & $3.6(+1.0)$ \\
\hline $\begin{array}{l}\text { Awareness of } \\
\text { undergraduate } \\
\text { research opportunities }\end{array}$ & 2.0 & 3.9 \\
\hline $\begin{array}{l}\text { Opportunity to } \\
\text { develop writing skills }\end{array}$ & 1.9 & 3.3 \\
\hline $\begin{array}{l}\text { Opportunity to reflect } \\
\text { on the learning } \\
\text { process }\end{array}$ & 2.9 & 3.8 \\
\hline $\begin{array}{l}\text { Knowledge of } \\
\text { learning style } \\
\text { contributed to } \\
\text { improvement in } \\
\text { learning }\end{array}$ & 3.0 & 3.3 \\
\hline $\begin{array}{l}\text { Experience with } \\
\text { mentoring was } \\
\text { positive }\end{array}$ & & 3.8 \\
\hline $\begin{array}{l}\text { Importance of } \\
\text { continuing the } \\
\text { mentoring portion of } \\
\text { the course }\end{array}$ & & 3.8 \\
\hline
\end{tabular}

${ }^{a}$ The results in General Microbiology when a questionnaire was administered during the last day of classes. For items that were also on the first questionnaire, the differences between the end averages and the beginning averages are noted in parentheses. The following scale was used: 4, good; 3 , moderate; 2 , fair; 1 , very poor.
- the regulatory agencies that govern that industry, and

- the skills needed by a microbiologist to work in that industry.

An oral report on their progress was given by each team every 3 to 4 weeks. The entire team was called to the front, and the professor selected one group member at random to make the oral report. This gave students exposure to oral presentations and helped the professor monitor for positive interdependence within each team. Each student reported orally about three times during the semester. At the end of the semester, each team gave a 25-min electronic presentation as well as a written report on their industry. On the final examination, $30 \%$ of the questions came from information the teams had gathered from the local industries.

\section{RESULTS IN INDUSTRIAL MICROBIOLOGY}

On the final day of class, a questionnaire was administered to evaluate the success of the course in increasing awareness of industrial microbiological processes among students. As shown in Table 4, significant gains were made in all but one of the areas common to the first questionnaire and the second one. Students also overwhelmingly agreed that the opportunity to work in groups was beneficial.

Attrition rates tend to be low in the Industrial Microbiology course. Since only one section is taught during the academic year, grade comparisons were not possible. The different approach to the course required different assessment instruments, so no comparison with previous years was possible, either. However, the grade distributions demonstrate that most students successfully completed the course $(93 \%$ passed with a grade of $\mathrm{A}, \mathrm{B}$, or $\mathrm{C}$, while nobody received a D, $2 \%$ failed, and $4 \%$ withdrew), even though the course had a heavy workload.

Student comments on the end of the semester questionnaire fell into the following categories. A total of $71 \%$ of the students felt that the course offered them a realistic view of the role of a microbiologist in industry and of their future careers. Three students commented on how the course integrated theory and practice. Five students remarked that they enjoyed the course very much.

TABLE 3. Distribution of grades for General Microbiology in the three sections taught by the same professor

\begin{tabular}{c|c|c|c}
\hline \multirow{2}{*}{ Grade } & \multicolumn{3}{|c}{ Result for group (\%) } \\
\cline { 2 - 4 } & $\begin{array}{c}\text { Control } \\
(24 \text { students })\end{array}$ & $\begin{array}{c}\text { Treatment } \\
(29 \text { students })\end{array}$ & $\begin{array}{c}\text { Treatment } \\
(24 \text { students })\end{array}$ \\
\hline A & 25 & 52 & 46 \\
\hline B & 54 & 24 & 33 \\
\hline C & 13 & 18 & 13 \\
\hline D & 0 & 3 & 4 \\
\hline F & 4 & 0 & 4 \\
\hline W & 4 & 3 & 0 \\
\hline
\end{tabular}


TABLE 4. Questionnaire results for Industrial Microbiology $^{a}$

\begin{tabular}{l|c}
\hline \multicolumn{1}{c|}{ Questionnaire item } & $\begin{array}{c}\text { Avg response } \\
(1 \text { section, } \\
46 \text { students })\end{array}$ \\
\hline $\begin{array}{l}\text { Knowledge of local } \\
\text { pharmaceutical industry }\end{array}$ & $3.6(+1.2)$ \\
\hline $\begin{array}{l}\text { Knowledge of the role of a } \\
\text { microbiologist in industry }\end{array}$ & $3.9(+1.5)$ \\
\hline $\begin{array}{l}\text { Knowledge of regulatory } \\
\text { agencies }\end{array}$ & $3.7(+1.4)$ \\
\hline $\begin{array}{l}\text { Knowledge of GMP (Good } \\
\text { Manufacturing Process) }\end{array}$ & $3.8(+2.3)$ \\
\hline $\begin{array}{l}\text { Knowledge of SOP (Standard } \\
\text { Operating Procedure) }\end{array}$ & $3.7(+2.1)$ \\
\hline $\begin{array}{l}\text { Knowledge of environmental } \\
\text { testing }\end{array}$ & $3.6(+1.3)$ \\
\hline $\begin{array}{l}\text { Knowledge of culture media } \\
\text { used for quality controls }\end{array}$ & $3.5(+1.5)$ \\
\hline $\begin{array}{l}\text { Knowledge of nonconventional } \\
\text { methods used to identify } \\
\text { microorganisms }\end{array}$ & $3.5(+1.5)$ \\
\hline $\begin{array}{l}\text { Experience with oral } \\
\text { presentations }\end{array}$ & $3.8(+1.2)$ \\
\hline $\begin{array}{l}\text { Experience with written reports } \\
\text { work in a group }\end{array}$ & $3.7(+0.3)$ \\
\hline $\begin{array}{l}\text { The resuls in Industial } \\
\text { Knicrob }\end{array}$ & 3.7 \\
\hline
\end{tabular}

${ }^{a}$ The results in Industrial Microbiology when a questionnaire was administered during the last day of classes. For items that were also on the first questionnaire, the differences in the end averages and the beginning averages are noted in parentheses. The following scale was used: 4, good; 3 , moderate; 2 , fair; and 1 , very poor.

\section{CONCLUSIONS}

This study confirmed that microbiology classrooms are scenes of diverse learning styles. Professors should rise to the challenge to better meet the needs of all their students. Teaching strategies that allow for more active learning on the part of the student should be implemented (16). With the predominance of active and visual styles for the students in this study, the professor decided to incorporate cooperative learning activities in addition to the traditional lectures.

Besides implementing different kinds of activities, professors should consider presenting material in such a way that it not only interests the students, but also prepares them for today's workforce. The curriculum can easily be enhanced with experiences that bring the real world to the classroom and that provide opportunities for the students to develop communication and interpersonal skills. The research work environment does not need to be divorced from the course; instead, it can be incorporated to complement course materials.

\section{NOTE}

The Soloman and Felder instrument to assess learning styles, Index of Learning Styles, is available electronically at http://www2.ncsu.edu/effective_teaching/.

\section{ACKNOWLEDGMENTS}

The student mentors were supported by a Puerto Rico Alliance for Minority Participation grant (HRD-9623943) from the National Science Foundation.

\section{REFERENCES}

1. Advisory Committee to the National Science Foundation Directorate for Education and Human Resources. 1996. Shaping the future: new expectations for undergraduate education in science, mathematics, engineering and technology, p. iii. National Science Foundation, Arlington, Va.

2. Anderson, R. 1997. Recommendations for the introductory microbiology laboratory core curriculum. Focus Microbiol. 4(1):2. 3. Association of Industries in Puerto Rico. 1998. Report of the education committee on the industrial needs in Puerto Rico. Association of Industries in Puerto Rico, San Juan, P.R.

4. Astin, A. W. 1993. What matters in college: four critical years revisited. Jossey Bass, San Francisco, Calif.

5. Barr, R. B., and J. Tagg. 1995. From teaching to learning-a new paradigm for undergraduate education. Change November/ December: 13-25.

6. Brown, J., A. Collins, and P. Duguid. 1989. Situated cognition and the culture of learning. Educ. Res. 18(1):32-42.

7. Buxeda, R. J., and D. A. Moore. 1999. Using learning styles data to design a microbiology course. J. Coll. Sci. Teaching 29(3):159-164.

8. Douthwright, J. 1994. Undergraduate microbiology curriculum recommendations. ASM News 60:460-461.

9. Ewell, P. T. 1997. Organizing for learning a new imperative. AAHE Bull. 50(4):3-6.

10. Felder, R. M. 1993. Reaching the second tier-learning and teaching styles in college science education. J. Coll. Sci. Teaching 23(5):286-290.

11. Felder, R. M., and L. K. Silverman. 1988. Learning and teaching styles in engineering education. Eng. Educ. 78(7):674.

12. Johnson, D. W., and R. T. Johnson. 1993. What we know about cooperative learning at the college level. Coop. Learning Mag. Coop. Higher Educ. 13(30):17-18.

13. Johnson, D. W., R. T. Johnson, and K. A. Smith. 1991. Active learning: cooperation in the classroom. Interaction Press, Edina, Minn.

14. Leinhardt, G. 1988. Situated knowledge and expertise in teaching, p. 146-168. In J. Calderhead (ed.), Teacher's professional learning. Falmer Press, London, United Kingdom.

15. Leinhardt, G. 1992. What research on learning tells us about teaching. Educ. Leadership April:20-25.

16. McKeachie, W. 1980. Improving lectures by understanding students' information processing: learning, cognition and college teaching. New directions for teaching and learning, no. 2. JosseyBass, San Francisco, Calif.

17. Papalia, D., and O. Wendkos. 1989. Human development. McGraw-Hill, New York, N.Y. 
18. Slavin, R. E. 1991. Synthesis of research on cooperative learning. Educ. Res. 4(1):67-77.
19. Slavin, R. E. 1993. What post secondary cooperative learning learns from elementary and secondary research. Coop. Learning Coll. Teaching 4(11):2-3.

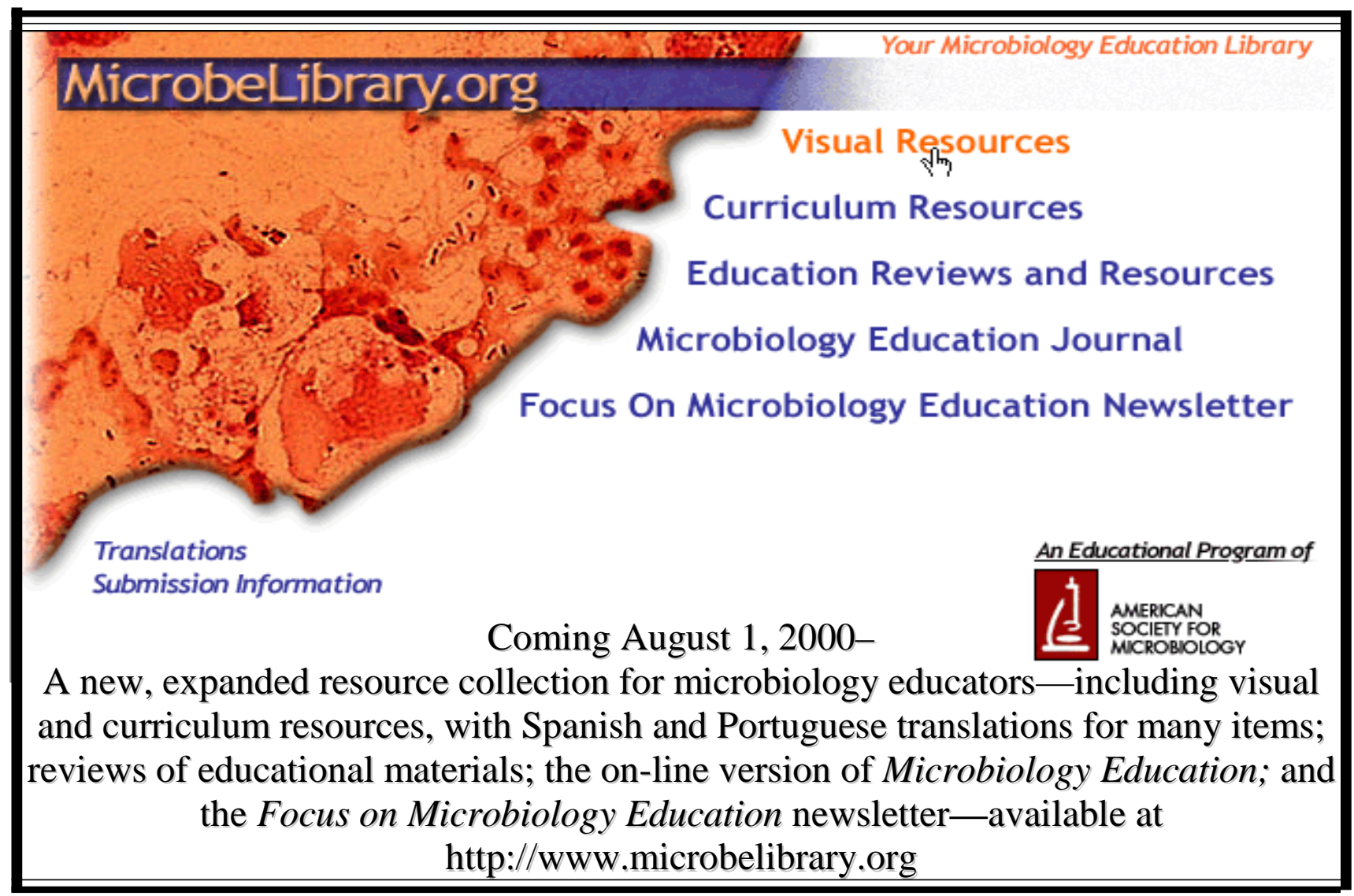

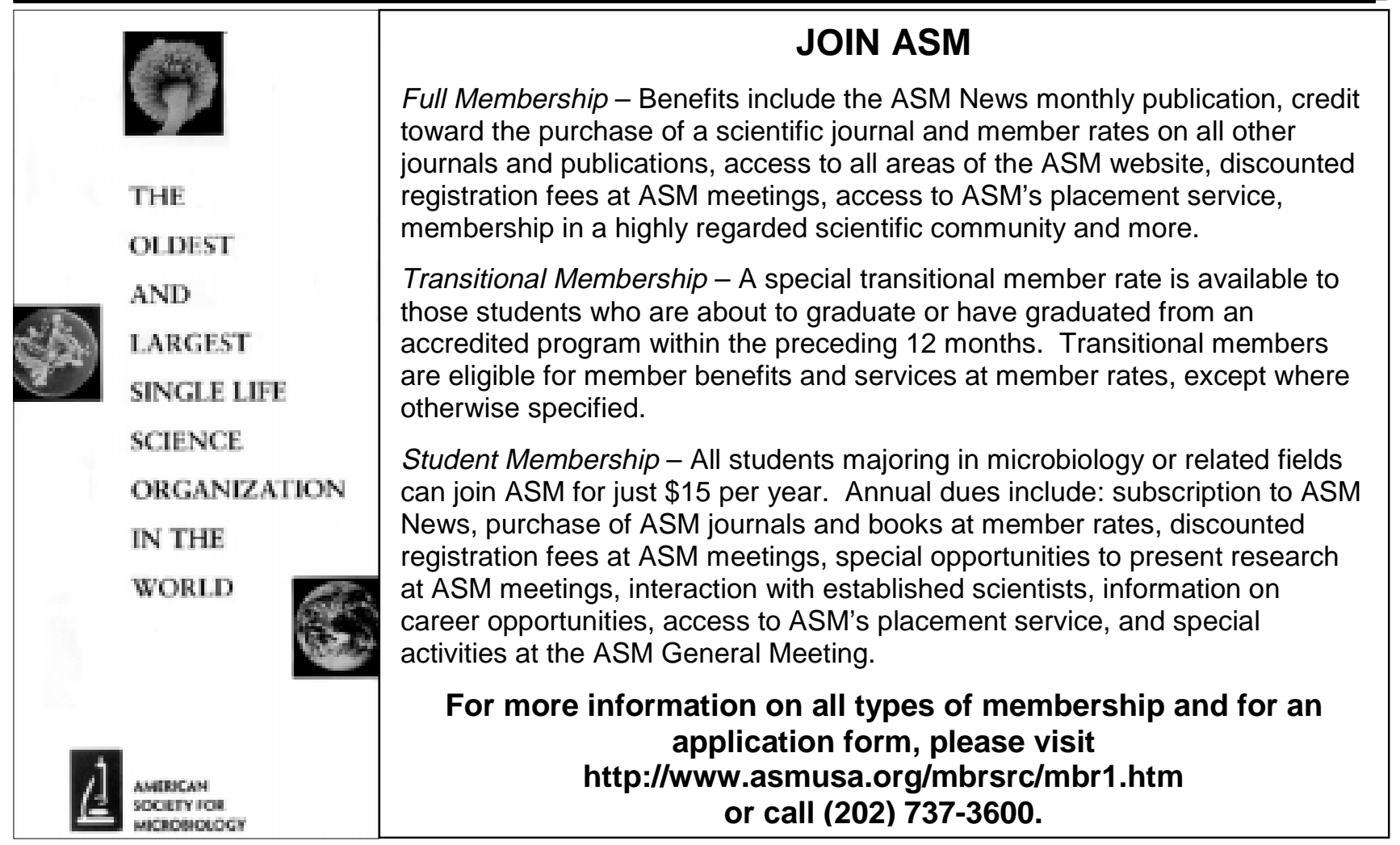

